\title{
Study of lung function changes among different grades of byssinosis
}

\author{
Y. M. EL-SADIK, M. MOSELHI, A. R. EL-HINADY, and M. N. MOSTAFA \\ High Institute of Public Health and Faculty of Medicine, Alexandria University, U.A.R.
}

\begin{abstract}
El-Sadik, Y. M., Moselhi, M., El-Hinady, A. R., and Mostafa, M. N. (1972). Brit. J. industr. Med., 29, 184-187. Study of lung function changes among different grades of byssinosis. This study comprised 80 workers of whom 50 are byssinotics, 15 are chronic asthmatic bronchitics, and 15 are free of chest symptoms.

A comparison of the changes in forced expiratory volume in one second due to exposure in the first working day in the week among them ( 80 workers) showed a greater reduction in byssinotics than among the others. Reduced maximum expiratory flow rates were found only in byssinotics. Independent of exposure, only third-grade byssinotic cases ( 22 out of 50 ) showed changes in predicted vital capacity, residual volume, total lung capacity, three seconds per cent vital capacity, total vital capacity timed in seconds, and air velocity index.

The pattern of changes in these lung functions is mostly obstructive; only two cases showed the pattern of restrictive disease.

This study denotes that two types of changes in pulmonary functions occur due to byssinosis. The first type is a temporary change in pulmonary functions which occurs only on exposure to the aetiological factor (cotton or flax dust). This type occurs among all grades of the disease. The nature of this type is obstructive. The second type of change is permanent. This type occurs only among the third grade of the disease and is not dependent on immediate exposure. This type of change is mostly obstructive but may show some restriction.
\end{abstract}

Exposure to cotton dust is associated with a fall in the ventilatory capacity during the work shift (McKerrow, McDermott, Gilson, and Schilling, 1958). El Batawi, Schilling, Valić, and Walford (1964) mentioned that in workers suffering from byssinosis this fall is marked.

Forced expiratory volume in one second $\left(\mathrm{FEV}_{\mathbf{1 . 0}}\right)$ decreases significantly during the shift in workers with a history of byssinosis, and such reduction increases according to the severity of the disease (Valić et al., 1968).

Others mentioned that $\mathrm{FEV}_{\mathbf{1 . 0}}$ is lower among byssinotics than normals (Lammerset al., 1964). Vital capacity (VC) was used for determination of the specific reduction changes occurring in byssinotic cases, and the results obtained were similar to that for $\mathrm{FEV}_{1 \cdot 0}$ (McKerrow et al., 1958; Žuškin and Valić 1966; Valić et al., 1968). McKerrow and his associates (1958) showed an increase in airway resistance among grade 1 and 2 byssinotic cases.

The aim of this study is to compare the changes in some of the above-mentioned lung functions among different byssinotic grades, chronic asthmatic bronchitics, and symptom-free individuals during shift exposure, and to study other lung functions among the byssinotics independent of their exposure.

\section{Material and method}

The study included 15 chronic asthmatic bronchitics, 15 symptom-free workers, and 50 byssinotics who were diagnosed according to the Roach and Schilling (1960) questionnaire with certain modifications in accordance 
with our culture and background experience of this disease. All workers (80) were from the cardrooms of a cotton textile plant. A chest radiograph was done on all cases to exclude any with findings that could not be explained by his present diagnosis. For each of the 80 individuals, $\mathrm{FEV}_{1 \cdot 0}$ and maximum expiratory flow rate (MEFR) were measured before and after the end of the first shift on the first working day in the week using a McKesson Vitalor Model VC-25. Each individual was trained to use the apparatus. Five readings were recorded for each individual. The first two readings were considered as an assurance of familiarity of the individual with the apparatus. The mean for such measurements was obtained from the last three readings. Any case showing a difference of more than $10 \%$ between the last three recorded readings led us to repeat the procedure.

Independent of exposure the following lung function tests were measured only for byssinotics (50). Residual volume (RV) was obtained using a Godart Nitrograph apparatus with the open circuit method. Timed vital capacity was obtained by timing the vital capacity expired as rapidly as possible on the revolving kymograph at its fastest speed $(2 \mathrm{~mm} / \mathrm{sec})$ using a 9 litres Lode D-51 spirograph equipped with an oxygen bell for volume stabilization. From RV and VC the total lung capacity (TLC) was calculated. Predicted values for VC and TLC were obtained using the equation given by Baldwin, Cournand, and Richards (1948). The predicted values were adjusted for height and age, and they were based on U.S. Veterans as there are no published figures for Arabs. U.S. Veteran values were accepted by us as they are similar to those of normal Egyptians shown in a pilot unpublished study. Air velocity index (AVI) was obtained from Gaensler's (1950) equation.

About 30 minutes' rest was given for each individual before he was subjected to the measurement of the previously mentioned pulmonary functions, and also each individual was trained to use the apparatus before the beginning of each test. Lung functions were measured while the worker was seated. Each measurement was repeated three times. All lung volumes were expressed at body temperature under the prevailing barometric pressure saturated with water vapour (BTPS).

\section{Results and discussion}

The results are shown in Tables 1 to 4 .

Table 1 shows the changes in FEV 1.0 and MEFR for different grades of byssinosis, chronic asthmatic bronchitis, and those free of symptoms due to the morning shift exposure ( 7 a.m. to 3 p.m.) in the first working day in the week. All the byssinotic cases showed a reduction in $\mathrm{FEV}_{\mathbf{1 . 0}}$. This reduction ranged from a mean of $22 \%$ among the first-grade cases (12), to $31 \%$ among the third-grade cases (22). Secondgrade cases (16) showed a mean reduction of $24 \%$.

The change in $\mathrm{FEV}_{1.0}$ among the chronic asthmatic bronchitics (15) and the symptom-free individuals (15) was a reduction of $3 \%$ for each. So one can say that exposure to cotton dust leads to a drop in $\mathrm{FEV}_{1.0}$; this does not exceed $5 \%$ in those free of symptoms or in chronic asthmatic bronchitics. The drop is greater among byssinotics and this increases with the progress of the disease. This agrees with the findings of Valić and others (1968).

The change in MEFR among byssinotics was a reduction varying from 25 to $30 \%$. There was no change in MEFR among symptom-free individuals or those suffering from chronic asthmatic bronchitis. These two lung tests can be used to confirm the diagnosis of byssinosis.

Table 2 shows the percent of predicted VC, RV, TLC and percent of residual volume to total lung capacity among different grades of byssinosis. These values do not differ from the normal among firstgrade and second-grade byssinotic cases. Only the third-grade byssinotic cases showed a significant difference from normal, a reduction in VC and TLC and an increase in $\mathrm{RV}$ and in the ratio of the residual volume to the total lung capacity.

Table 3 shows the first second and 3 seconds percent VC and total VC among the byssinotic cases.

Significant changes in these measurements are present among third-grade byssinotics (22 cases). These changes are a reduction in first second percent of VC and 3 seconds percent of $\mathrm{VC}$ and an increase in the time of the total VC.

Table 4 shows the AVI among different grades of byssinosis. The AVI differs significantly from normal only among third-grade cases. These had an AVI of less than one. Tables 2,3 , and 4 show that first- and

TABLE 1

Changes in FEV $_{1.0}$ And MEFr before and after the Shift among Different Grades of Byssinosis, Chronic Asthmatic Bronchitics, and Symptom-free Subjects

\begin{tabular}{|c|c|c|c|c|c|c|c|c|c|c|}
\hline \multirow{2}{*}{ Diagnosis } & & & & \multirow{2}{*}{ No. } & \multicolumn{3}{|c|}{$F E V_{1.0}$} & \multicolumn{3}{|c|}{$M E F R(l)}$. \\
\hline & & & & & Before & Aftcr & $\%$ reduction & Before & After & $\%$ reduction \\
\hline $\begin{array}{l}\text { First-grade byssinosis } \ldots \\
\text { Second-grade byssinosis } \\
\text { Third-grade byssinosis ... } \\
\text { Chronic asthmatic bronchitis } \\
\text { Symptom-free .. . . }\end{array}$ & $\begin{array}{l}\cdots \\
\cdots \\
\cdots \\
\cdots \\
\cdots\end{array}$ & $\begin{array}{l}\cdots \\
\cdots \\
\cdots \\
\cdots \\
\cdots\end{array}$ & $\begin{array}{l}\cdots \\
\cdots \\
\cdots \\
\cdots \\
\cdots\end{array}$ & $\begin{array}{l}12 \\
16 \\
22 \\
15 \\
15\end{array}$ & $\begin{array}{l}3 \cdot 1 \\
3 \cdot 0 \\
1 \cdot 5 \\
1 \cdot 97 \\
2 \cdot 20\end{array}$ & $\begin{array}{l}2 \cdot 4 \\
2 \cdot 3 \\
1 \cdot 04 \\
1 \cdot 90 \\
3 \cdot 10\end{array}$ & $\begin{array}{r}22 \\
24 \\
31 \\
3 \\
3\end{array}$ & $\begin{array}{l}397 \\
372 \\
181 \\
215 \\
446\end{array}$ & $\begin{array}{l}298 \\
275 \\
127 \\
214 \\
445\end{array}$ & $\begin{array}{r}25 \\
26 \\
30 \\
0 \\
0\end{array}$ \\
\hline
\end{tabular}


TABLE 2

Percent of Predicted VC, RV, TlC and Percent of RV to TlC among Different Grades of BYSSINOSIS

\begin{tabular}{|c|c|c|c|c|c|c|c|c|c|c|c|c|c|c|}
\hline \multirow{2}{*}{\multicolumn{2}{|c|}{$\begin{array}{c}\text { Grade of } \\
\text { byssinosis }\end{array}$}} & \multirow[t]{2}{*}{ No. } & \multicolumn{3}{|c|}{$\%$ predicted VC } & \multicolumn{3}{|c|}{$\%$ predicted $R V$} & \multicolumn{3}{|c|}{$\%$ predicted $T L C$} & \multicolumn{3}{|c|}{$R V / T L C \%{ }^{1}$} \\
\hline & & & Mean & S.D. & $t$ & Mean & S.D. & $t$ & Mean & S.D. & $t$ & Mean & S.D. & $t$ \\
\hline First & . & 12 & 102 & $4 \cdot 7$ & $\begin{array}{c}+1 \\
\text { (N.S.) }\end{array}$ & 102 & $10 \cdot 3$ & $\begin{array}{r}+0.7 \\
\text { (N.S.) }\end{array}$ & 102 & $5 \cdot 7$ & $\begin{array}{c}+1 \cdot 2 \\
\text { (N.S.) }\end{array}$ & 26 & $3 \cdot 2$ & $\begin{array}{c}+1 \cdot 1 \\
\text { (N.S.) }\end{array}$ \\
\hline Second & $\cdots$ & 16 & 102 & $7 \cdot 8$ & $\begin{array}{c}+1 \\
\text { (N.S.) }\end{array}$ & 104 & $9 \cdot 9$ & $\begin{array}{l}+1 \cdot 6 \\
\text { (N.S.) }\end{array}$ & 102 & $4 \cdot 3$ & $\begin{array}{r}+1.9 \\
\text { (N.S.) }\end{array}$ & 26 & $3 \cdot 2$ & $\begin{array}{l}+1 \cdot 25 \\
\text { (N.S.) }\end{array}$ \\
\hline Third & . & 22 & 81 & $7 \cdot 9$ & $\begin{array}{c}-11 \cdot 3 \\
(S)\end{array}$ & 141 & 55 & $\begin{array}{l}+3.5 \\
(\mathrm{~S})\end{array}$ & 95 & $12 \cdot 3$ & $\begin{array}{r}-2 \\
\text { (N.S.) }\end{array}$ & 34 & $9 \cdot 6$ & $\begin{array}{c}+4 \cdot 4 \\
(\mathrm{~S})\end{array}$ \\
\hline
\end{tabular}

${ }^{1}$ Normal $=25$ (Comeroe, 1951$)$

N.S. $=$ not significant at $1 \%$ level

$\mathbf{S}=$ significant.

TABLE 3

First and 3 Seconds Percent VC and Total VC Time (Seconds) among Different Grades of BYSSINOSIS

\begin{tabular}{|c|c|c|c|c|c|c|c|c|c|c|c|}
\hline \multirow{2}{*}{\multicolumn{2}{|c|}{$\begin{array}{c}\text { Grade of } \\
\text { byssinosis }\end{array}$}} & \multirow{2}{*}{ No. } & \multicolumn{3}{|c|}{ First second $\%$ of $V C^{1}$} & \multicolumn{3}{|c|}{3 seconds $\%$ of $V C^{2}$} & \multicolumn{3}{|c|}{ Total VC time $e^{3}$} \\
\hline & & & Mean & S.D. & $t$ & Mean & S.D. & $t$ & Mean & S.D. & $t$ \\
\hline First & .. & 12 & 78 & $10 \cdot 1$ & -1.73 & 98 & $2 \cdot 8$ & $\begin{array}{l}+1 \cdot 25 \\
\text {. }\end{array}$ & $3 \cdot 4$ & 0.8 & - \\
\hline Second & .. & 16 & 78 & $8 \cdot 3$ & $\begin{array}{l}-2 \cdot 4 \\
\text { (N.S.) }\end{array}$ & 96 & $4 \cdot 2$ & $\begin{array}{l}-1 \\
\text { (N.S.) }\end{array}$ & $3 \cdot 8$ & $1 \cdot 2$ & 一 \\
\hline Third & .. & 22 & 52 & 15 & $\begin{array}{l}-9 \cdot 7 \\
\text { (S) }\end{array}$ & 79 & 15 & $\begin{array}{c}-5 \cdot 6 \\
\text { (S) }\end{array}$ & 7 & $1 \cdot 7$ & $\begin{array}{c}+6 \cdot 5 \\
(\mathrm{~S})\end{array}$ \\
\hline
\end{tabular}

${ }^{1}$ Normal $=83 \% \quad$ (Gaensler, 1950)

${ }^{2}$ Normal $=97 \% \quad$ (Gaensler, 1950)

${ }^{3}$ Normal $=4 \mathrm{sec} \quad$ (Gaensler, 1950)

N.S. = not significant at $1 \%$ level $\mathrm{S}=$ significant at $1 \%$ level

TABLE 4

Air Velocity IndeX among Different Grades OF BYSSINOSIS

\begin{tabular}{|c|c|c|c|c|c|}
\hline \multirow{2}{*}{\multicolumn{2}{|c|}{ Grade of byssinosis }} & \multirow{2}{*}{ No. } & \multicolumn{3}{|c|}{ Air velocity index 1} \\
\hline & & & Mean & S.D. & $t$ \\
\hline First & & 12 & 0.99 & $0 \cdot 1$ & $\begin{array}{r}-0.33 \\
\text { (N.S.) }\end{array}$ \\
\hline Second & $\ldots$ & 16 & 0.98 & $0 \cdot 1$ & $\begin{array}{c}-0.8 \\
\text { (N.S.) }\end{array}$ \\
\hline Third & . & 22 & 0.69 & $0 \cdot 19$ & $\begin{array}{c}-7 \cdot 7 \\
\text { (S) }\end{array}$ \\
\hline
\end{tabular}

${ }^{1}$ Normal $=1$ (Gaensler, 1950)

N.S. = not significant at $1 \%$ level $\mathrm{S}=$ significant at $1 \%$ level second-grade byssinotics do not suffer from permanent effects on lung function. Third-grade cases suffer from permanent effects independent of exposure. All the lung function changes denote an obstructive element. This obstructive element may be due to an increase in airway resistance or to a reduction in lung elasticity.

Owing to the high standard deviation in RV among the third-grade byssinotic cases (Table 2) we tried to classify these cases according to the degree of change in RV, TLC, AVI, first second percent VC and total-time VC. According to this classification eight of the 22 third-grade byssinotic cases had a mean percent predicted RV of 201 (range 135-260), mean percent RV to TLC of 44 (range 29-52), mean first second percent VC of 41 (range 28-54), mean total VC of 10 seconds (range 7-13), and mean AVI 
of 0.48 (range $0.34-0.68$ ); this pattern of lung function denotes severe obstruction. Three cases had a mean percent predicted RV of $128(118-136)$, mean percent RV to TLC of 31 (range 28-35), mean first second percent VC of 50 (range 89-601), mean totaltime VC of 6 seconds (range 5-7), and mean AVI of 0.69 (range $0.64-0.73$ ); this lung function pattern denotes mild obstruction. Two cases had a mean percent predicted RV of 86 (range 79-92), mean percent RV to TLC of 23 (range 22-24), first second percent VC for each of 78, mean total-time VC of 4.5 seconds (range 3-6), and mean AVI of 0.97 (range $0.93-1 \cdot 0)$; this pattern of lung function shows the liability of restrictive element. The remaining nine cases show values for lung functions which denote both obstructive and restrictive elements.

This study shows that two types of changes in pulmonary functions occur due to byssinosis. The first is a temporary change in pulmonary functions which occurs only on exposure to the aetiological factor (cotton or flax dust). This type is seen among all grades of the disease and is of an obstructive nature.

The second type of change is permanent. This type occurs only among third-grade byssinotics and it does not depend on exposure. This type of change is mostly of an obstructive nature but it may also be restrictive.

\section{References}

Baldwin, E. de F., Cournand, A., and Richards, D. W. (1948).
Pulmonary insufficiency. I. Physiological classification, clinical methods of analysis, standard values in normal subjects. Medicine (Baltimore), 27, 243-278.

El Batawi, M. A., Schilling, R. S. F., Valić, F., and Walford, Joan (1964). Byssinosis in the Egyptian cotton industry: changes in ventilatory capacity during the day. Brit. J. industr. Med., 21, 13-19.

Comeroe, J. H. Jr. (1951). Interpretation of commonly used pulmonary function tests. Amer. J. Med., 10, 356.

Gaensler, E. A. (1950). Air velocity index. Amer. Rev. Tuberc., 62, 17-28.

Lammers, B., Schilling, R. S. F., Walford, Joan, Meadows, Susan, Roach, S. A., van den Hoven van Genderen, D., van der Veen, Y. G., and Wood, C. H. (1964). A study of byssinosis, chronic respiratory symptoms, and ventilatory capacity in English and Dutch cotton workers, with special reference to atmospheric pollution. Brit.J. industr. Med., 21, 124-134.

McKerrow, C. B., McDermott, M., Gilson, G. C., and Schilling, R. S. F. (1958). Respiratory function during the day in cotton workers: a study in byssinosis. Brit. $J$. industr. Med., 15, 75-83.

Roach, S. A., and Schilling, R. S. F. (1960). A clinical and environmental study of byssinosis in the Lancashire cotton industry. Brit. J. industr. Med., 17, 1-9.

Valić, F., Žuškin, E., Walford, Joan, Keršić, W., and Pauković, R. (1968). Byssinosis, chronic bronchitis, and ventilatory capacities in workers exposed to soft hemp dust. Brit. J. industr. Med., 25, 176-186.

Žuškin, E., and Valić, F. (1966). Acute effects of hemp dust on ventilatory capacity. In Proceedings of 15 th International Congress on Occupational Health, Vienna, 1966, vol. 3, pp. 291-294.

Received for publication July 7, 1971. 